\title{
Fearing the knock on the door: critical security studies insights into limited cooperation with disaster management regimes
}

\author{
Ryerson Christie ${ }^{1 *}$, Olivia Cooke ${ }^{2}$ and Joachim Gottsmann ${ }^{2}$
}

\begin{abstract}
In seeking to provide for the safety of local communities in the global south, there has been an apparent policy focus on making early warning systems more robust, and improving the operation of disaster management programmes. However, the critical security studies literature has highlighted the ways in which security practices, including those nominally implemented on behalf of local communities can have negative impacts on peoples. Human security literature, in particular, highlights the ways in which the state security apparatus, which is often relied upon to notify and enforce evacuations, may often be perceived as a serious risk to communities. At the same time individuals live within complex security situations where daily threats to peoples' lives may outweigh geological hazards. Grounded within critical literature on the social construction of risk (Lupton; Beck, Douglas), the ways in which volcanic risk is calculated, communicated, and enacted upon, will be assessed in relation to the local communities' security dilemmas.

Drawing on field work in communities at risk from lahars generated from Cotopaxi in Sangolqui, Ecuador, explores the ways in which competing claims of what constitutes security challenge the operating assumptions in emergency preparedness. In June 2012, 158 primary interviews were undertaken as a part of the EU funded VUELCO project in Ecuador. The findings were analyzed using quantitative and qualitative methodologies, drawing most heavily on interpretive methodologies to argue that the scientific representation of volcanic hazards, and the resultant disaster management strategies, do not account for local context. Indeed, the majority of interviewees indicated a lack of trust in either scientific expertise or government representatives, on questions of security. By incorporating a broader narrative of security beyond a narrow focus on natural hazards, disaster preparedness and communication plans can be more effective.
\end{abstract}

Keywords: Risk; Lahars; Disaster management; Volcanology

\section{Introduction}

The past decade has seen a proliferation of literature that can be broadly classed as belonging to social volcanology. This body of work, which has antecedents within disaster and risk literatures, is fundamentally concerned with the ways in which volcanological hazards impact upon individuals and communities, and how communities are able to prepare and respond to such impacts. At

\footnotetext{
* Correspondence: ryerson.christie@bristol.ac.uk

${ }^{1}$ School of Sociology, Politics and International Studies (SPAIS), University of Bristol, Bristol BS8 1TU, UK

Full list of author information is available at the end of the article
}

the heart of this literature is the recognition that disasters do not 'just happen, and that they do not effect people/s in an equal manner. These approaches, drawing on development and disaster literatures have an abiding interest in perceptions of risk, and vulnerabilities, in the social formations that put some at greater risk than others. This has in turn translated into calls for greater local engagement in disaster risk reduction (DRR) strategies.

This social turn has been crucial in understanding the complex decision-making, and the impact of power relations, on communities at risk from natural hazards. It has also challenged views, still prevalent in policy

\section{它 Springer}


communities, that local people are either ignorant of the threats they face, or are making poor decisions. Focusing on vulnerabilities has highlighted how structural barriers exist, limiting the ability of people to effectively engage in DRR. What has gone underexplored are the broader insecurities that people face, and how these partially shape decision-making. This paper seeks to contribute to the social volcanology literature by demonstrating how a specific focus on the narratives of insecurities complements the vulnerabilities approaches. In particular, such an approach emphasizes how a volcanic hazard is considered as part of a broader continuum of threat, and secondly how trust in disaster management regimes is impacted by the confidence people have in the broader state security architecture.

\section{Background}

Social volcanology has evolved rapidly over the past fifteen years, with a growing recognition amongst academics and practitioners of the centrality of culture, economics, and power, in shaping perceptions and responses to natural hazards. At the same time, despite public commitments to public engagement and local empowerment, policy communities have been slow to embrace the social turn (Cordona 2003;). In at least some states there is still a preponderance of technocratic formulations of the 'objective' risk of volcanoes, which either ignores or undervalues 'outsider' or local knowledge and experiences.

Within policy debates and discussions of natural hazard risk mitigation, particularly in relation to volcanic hazards, there remains a significant focus on realist positions where risk is expressed in probabilistic and actuarial terms. Thus, in Adams' (1995: 69) widely cited definition, "risk... is the probability of an adverse future event multiplied by its magnitude". This has been transferred directly into some analysis of volcanic threats, for example in the work of Jóhannesdóttir and Gísladóttir (2010) on volcanic risk perception in Iceland.

Risk is a product of the likelihood of an incident occurring and its possible consequences. It could be the suffering of harm or loss from a hazard that can cause injury, disease, economic loss or environmental damage. It is expressed in terms of probability - a mathematical statement about the probability of an occurrence (Miller, 1995). (Jóhannesdóttir and Gísladóttir 2010:411)

This means that risk perception, following logically, must then be related specifically to the particular threat, and restricts our ability to place one 'risk' in relation to broader concerns of individuals and communities. Such a view has clear policy implications, resulting in risk mitigation plans that are predominately developed and implemented in isolation from other risks to communities. This has led to the over-riding interest in the ways in which people living in communities 'at risk' from volcanic hazards perceive the 'threat' (Johnston et al. 2005 van Manen 2014; Tobin et al. 2011; Van der Pligt 1996; Wachinger et al. 2013).

This 'objective' risk is often treated as a given, and disaster management officials, occasionally in conjunction with scientific and technical advisors, decide upon appropriate and inappropriate forms of response. The technicians thus make assumptions about what constitutes a logical response to their own perception of the risk posed by natural hazards. In order to understand this apparent disconnect between appropriate response and the behavior of local peoples, efforts are made to understand the risky behavior. At this point there are often a series of surveys conducted that seek to determine the risk awareness of peoples living in the potential hazard zone (Njome et al. 2010; Dominey-Howes and Minos-Minopoulos 2004; Davis and Ricci 2004). Local understandings of the risk are assessed through questions (usually asked as a part of a formal questionnaire) that determine whether they have an accurate understanding of the nature of the threat, its likelihood (assessed according to whether they can accurately describe the determined probabilities), and crucially whether they would then react to an event in the desired manner. A series of questions are also asked with the intent of determining factors that might influence perception in order to identify factors that might interfere with the appreciation of the risk posed by the particular hazard. Underlying much of such work is the simple presumption that a logical individual would make a clear rational choice to minimize the risk posed by the natural hazard, and that they ought to make the anticipated decision.

At the same time, there is a growing recognition that risk perception is complex, and can be affected by a range of determinants, including age, education, culture, and gender. This has meant that many studies have taken a more holistic approach, seeking to understand how the risk is perceived more generally rather than focusing on the specific grasp of statistical risk. Thus, Jóhannesdóttir, and Gísladóttir have, for example, sought a more qualitative approach.

With respect to communities, assessments relying only on numbers, statistics and objective calculation, may not necessarily give the same information as those based on the assessment of emotional and subjective information (e.g. Otway 1992; Slovic 2000, 2004). (Jóhannesdóttir and Gísladóttir 2010: 411)

As Sjöberg (2000) argues, the perception of risk relates to beliefs and values on the one hand, while on the other 
the amount of time that has passed since previous events. While such analysis broadens the forms of analysis of perception, and provides some recognition of the power of affect - the emotional content of risk - it continues to prioritize the particular natural hazard. The effect of this analysis is to reproduce the particular natural hazard as the most pertinent to peoples' lives, with the clear policy implication being to increase the information provided by the particular risk in order to ensure appropriate behaviours are adopted by 'at risk' populations.

This privileging of particular voices in determining, not just the potential risk of a given event, but also what constitutes a responsible reaction on the part of individuals and communities, has received some attention (Perry and Lindell 2008). In particular, Irwin has stated that there is a clear 'scientistic voice' that argues that the public should only be involved in making decisions when it is "properly instructed and educated (Irwin 2006: 302)". Yet, Irwin's particular take on this issue is not to question the threat of the referent object itself, but rather to seek to demonstrate that people can have relatively accurate understandings of the event. Irwin goes through a number of papers that shows that people are often, and contrary to the expectation of 'experts' often quite well informed (Irwin 2006: 302). However, this still assumes that accurate understandings of the particular threat are essential.

Thus, much of the literature assumes a direct correlation between an 'accurate perception' of the risk and the likelihood that people will undertake the appropriate form of action (Carlino et al. 2008; Mileti and Sorensen 1990; Lindell 1994). There is a broad belief that nonscientists lack the detailed knowledge of the geological processes driving volcanoes, or of the precise nature of the hazards related to living near a volcano, which is expected to impact on understandings of the basic risks. Where peoples' narratives of the risk, and their ability to describe volcanic systems, fails to replicate the 'official' line, cognitive analysis tends to be used to explain why correct perceptions are obscured (Slovic et al. 2004; Fischhoff et al. 2000, Fischhoff et al. 2000; Slovic 2000; Kerlinger and Lee 2000. Such formulations obscure the complexities within which individuals and communities live, which have been highlighted within the sociological and anthropological literatures on volcanic hazards and DRR. Crucially, this literature shifts from the issue of peoples' singular perception of hazards and risks, to emphasize why people are exposed to hazards.

While DRR strategies often continue to rely in practice on technocratic understandings of risk, when it comes to the local perceptions of threats there is a clear recognition that the understandings of risk are socially and economically contextualized (Gaillard 2008, Lavigne et al. 2008; and Dibben 2008). As such within the social volcanology literature there is an emerging preference for sociological and anthropological approaches. Anthropological literatures on volcanic hazards (Cashman and Cronin 2008; Chester et al. 2008; Dixon et al. 1999; Dove 2008), for example, tend to explore the role of symbolic meaning and representation of natural hazards, and how risk is represented and understood within different cultural systems. Cashman and Cronin (2008), for example, explore the ways in which experiences of volcanic activities can result in sufficient psychological trauma that people challenge, and as a result alter, their cosmologies. Following the Boxing Day Tsunami a series of studies on indigenous communities in the Indian Ocean demonstrated how ancestral knowledge can be crucial in DRR. Gaillard, in a series of studies (Gaillard 2003, 2007, 2008, 2010), has further demonstrated the importance of traditional knowledge in the resilience of communities living with volcanological hazards. As Lavigne et al. (2008) state, “...people's behavior is disconnected from the sole threat posed by the hazard to which the individual is exposed (Lavigne et al. 2008: 274)". They then ask how the objective risk differs from the perceived risk, and how this is adjudicated by social values, traditions, and sense of community and place. They also look at the ways in which social and economic forces impact upon perceptions and responses. Thus, understanding local culture is seen as essential to ensure effective DRR (Mercer et al. 2012; Donovan 2008, 2009; Chester 2005b; Oliver-Smith 1996; Perry and Lindell 2008). This is essential research, and has contributed greatly to understandings of local community perceptions and behaviors towards natural hazards.

The focus on communities, which is driven by both an ontological commitment to local knowledge, and a political imperative to empower communities in the face of natural hazards, has resulted in a push for bottom-up DRR or community based disaster risk reduction (CBDRR) (Alexander 2002; Allen 2006; Comfort 2012; Luna 2014; Paton et al. 2001). ${ }^{1}$ This re-orientation away from topdown disaster management,

...places greater value on local knowledge, local ownership, vulnerability and capacity assessments, and on participatory methods. [It] allows calculations about risk and uncertainty to be left to communities, who are expected to make choices about risk management decisions based on their own knowledge of the environment in which as they live and the livelihood options available to them. (Barclay et al. 2008: 169)

The promotion of participatory methods to mitigate disasters generally, and volcanic risk specifically, has been advanced by numerous scholars (Cronin et al., 2004; Cutter, 
2003; Donovan, 2009; Gaillard, 2008; Gaillard \& Mercer, 2012; Lane et al., 2011; Mercer, Kelman, Lloyd, \& SuchetPearson, 2008; Wisner, Blaikie, Cannon, \& Davis, 2004; Wisner, Gaillard, \& Kelman, 2012).

The focus on communities has been informed by disaster studies. From the mid 1970s onwards there has been a sustained engagement with issues arising from the recognition that societies are not equally exposed to natural hazards, and that the benefits of development do not accrue equitably (Alexander 1993; 1997; Allen 2006; Chester 2005a; Devereux 2001; Hewitt 1995; 1997; Wisner 1993). Within the narrower literature addressing volcanic hazards there is a substantial body of work that has engaged with vulnerability (Donovan 2008; Gaillard 2007; Enarson and Meyreles 2004; Fothergill and Peek 2004; Gregg et al. 2004; Lane et al. 2003; Tobin et al. 2002; Lavigne et al. 2008; Mercer et al. 2012; Chester et al. 1999). Gaillard argues that in its initial formulation, vulnerability referred to "the social construct leading people to be fragile in the face of natural hazards and food shortages (Gaillard 2010: 219)". This manifested in a drive to identify structural and local aspects of vulnerability.

...there has been a false separation of hazards and the social system because of the lack of widespread recognition of connections between the daily risks people face and the reasons for their vulnerability to hazards and disasters. Indeed, disasters are the products of the social, political, and economic environment, as well as the natural events that cause them. (Fothergill and Peek 2004: 89)

Building on McKnight (1977) and Wisner (1993), Gaillard (2007) moves away from the first generation of writing on vulnerability that stressed macro-scale structural and societal constraints, opting to stress that it is about the daily conditions of peoples (2010). Vulnerability is particularly acute for marginalized peoples (geographic, social in terms of poverty, and political in terms of their being silenced. This paper adopts Gaillard's definition, drawing on Cannon (1994) of vulnerability as "...condition of a society which makes it possible for a hazard to become a disaster (Gaillard 2007: 522). As Oliver-Smith (1996) argued, this vulnerability is a social construct, rather than being an inherent characteristic.

The discourse of vulnerability has become pervasive and informs a broad range of policy and academic documents (Wisner et al. 2014), and is at the core of the 2005-2015 Hyogo Framework for Action, and the new Sendai Framework for Disaster Risk Reduction, 2015 - 2030.

With the analysis still strongly situated on the object of the perceived risk, the broader range of perceived sources of insecurity is obscured. Indeed, as Oltedal et al. (2004) have argued, seeking to link risk perception to cultural adherence is exceptionally difficult to demonstrate, and "...cultural adherence does not seem to be a very precise predictor of risk perception (27)". These forms of analysis can return to the trope of the perception of the risk itself, taking the referent object's inherent threat for granted once determined by experts. The alternative approach is to focus more specifically on vulnerabilities within societies, seeking to understand how particular segments of populations are at greater risk from hazards, and how events are likely to impact disproportionately on subaltern groups.

\section{Insecurities}

The vulnerabilities literature has been a welcome, and crucial, advancement within social volcanology. However, the focus on relative deprivation along class, gender, religious, and racialized lines, has obscured at times other components of vulnerability, and has often failed to provide a space for communities to articulate what they perceive as the impediments to the lives they wish to pursue. As Hewitt (1983) argued, decision making is done in a complex manner, and take place in contexts where there are numerous concerns facing individuals and communities: "...in most places and segments of society where calamities are occurring, the natural events are about as certain as anything within a person's lifetime, or at least that of himself, his children and grandchildren (Hewitt 1983: 26)." Drawing on Hewitt (1983; 2007) and Bankoff (2001), Bankoff et al. (2004), and Mercer et al. (2008), highlight that technical experts in DRR, and indeed academics, focus on the preidentified hazard at the expense of the '...societal elements that may have contributed to vulnerability in the first place (74)...", a point echoed by Perry and Lindell (2008). This suggests that we need to not only examine cultural norms surrounding hazards, but that we also need to explore the contexts of broader perceptions of insecurities, and how there might be an adjudication between distinct sources of insecurities to life.

A refocus on human insecurity takes as its starting point the notion that the referent object, not the threat, has to be at the centre of analysis (Thomas and Tow 2002; Christie 2010). It then asks what is preventing the individual and/or communities from living the good life', sometimes expressed as freedom from fear, freedom from want, and freedom to live in dignity, rather than seeking in the first instance to understand a particular narrow band of practices in relationship to a pre-given hazard. Insecurities, then, are those concerns which people perceive as representing threats to their attainment of a desired life. This also requires that analysis avoids being prescriptive about what sources of insecurity are, allowing for a multitude of possible answers. 
This approach is rooted within critical security studies (Christie 2008; Krause 2004; Paris 2001), emerged as a corrective to traditional security studies with its emphasis on war. The argument that was made, beginning in the 1990s, was that a traditional focus on the threats failed to account for the ways in which people actually experienced the threats, or which threats were most salient to them. In this way the field of security studies, which in the past has focused on issues such as weapons of mass destruction, inter-state war, and terrorism, was forced to confront how communities were often most concerned (and most threatened) by issues such as crime, hunger, and under-development. This emerged as a result of a re-centering of attention away from the threats onto the referents (individuals and communities) themselves. This in part reflected the growing awareness in the 1990s that practices to provide security for populations, such as policing, surveillance, and broader military activities, often represented the most serious source of insecurity for peoples.

This is of direct relevance to the matter of natural hazards and the concern for preparing for large-scale events emanating from volcanic systems. Starting from the position of the people directly affected by the potential hazard, we need to ask first and foremost what they see as the sources of their insecurities. From we can then understand the broader field of concerns within which people are making decisions about their lives, and the lives of their families.

This flows naturally into a related line of enquiry into the extent to which people are willing to trust people on security issues, across the spectrum of identified insecurities. Just as insecurities from natural hazards exist within a range of other considerations, so do the various actors engaged in redressing insecurities. There is a broad range of people who impact on the decision making and behaviors of individuals and communities, and crucially they do not exist in isolation from one another, and are politically situated (meaning that peoples' interactions are not 'natural' in terms of being pre-ordained). This indicates, in part, that we can not focus exclusively on the scientific community when exploring issues of trust surrounding natural hazards, and that we need to look at levels of trust in relationship to other sources of insecurity.

\section{Social trust}

There is an old and well-established sociological literature on the role of trust in effecting peoples' perceptions and responses to disasters (Cvetkovich and Löfstedt 1999; Toya and Skidmore 2014). It is a truism, and tautological, that people will listen more to those they trust on particular issues. Within the literatures on risk, scholars have been particularly influenced by the idea that perceptions of risk are impacted by social trust, which is effected by the competence of the disaster management authorities as well as by cultural contexts (López-Vázquez 2009; Haynes et al. 2007, 2008; Poortinga et al. 2004). Within the study of natural hazards there is often an assumed equivalence between scientific knowledge and competence on the one hand, and that this should lead to trust and confidence (Siegrist et al. 2000; 2003), and that with respect to volcanic hazards/risks that scientists should be trust-worthy. In addition, considerable attention has been paid to the manner in which disasters impact upon the levels of trust (sometimes used a proxy for the broader concept of 'social capital') within societies (Toya and Skidmore 2014; Wachinger et al. 2013; White and Fu 2012; Fleming et al. 2014).

Yet, and this is recognized within the more nuanced writing on the topic, this narrative of superiority cannot be dissociated from the ways in which the local populations perceive the scientific expertise surrounding natural hazards (Haynes et al. 2007). Public and private claims about the ignorance of communities on the one hand likely serve to contribute to a perception of people of technical elites as being arrogant and out of touch. As Wynne (1983) illustrated with respect to populations' responses to technological elites, when communities reject technical advice, rather than resulting in a careful reflection on the part of the scientific experts, this serves to reinforce scientists' and disaster managers' beliefs in the "... irrationality of people, which justifies their further exclusion from processes of innovation and other decisions (Wynne 1983: 27)". This has to be assumed to affect the general level of trust placed in the scientific community. Irwin points out increased public engagement will not necessarily contribute to increased trust (Irwin 2006: 314). In reference to the Genetically Modified food debate Irwin observes that "... such deliberations may lead to the outcome of enhanced criticism and skepticism... (2006: 315)". We see then that the perception of expertise and the trust of communities are exceptionally complex, even in relationship to a single issue.

When examined in conjunction with the focus on narratives of insecurities this suggests a need to also explore the level of trust that people have in the broad range of security actors, not solely in relation to disaster management. The assumption is that the trust in DRR regimes will be inflected by the perceptions of the ability of the state to meet broader security concerns. This does not mean that the state and its agencies will be ignored during a time of crisis, but the possibility must be entertained. Rather than focusing on issues of trust relating to natural hazards, it is crucial to understand how people perceive the state's actions in relation to broader security concerns. 


\section{Cotopaxi and lahar hazards}

There is little doubt that Cotopaxi has the potential to pose a significant threat to human life and infrastructure. There have been numerous studies of the evolution of the stratovolcano by: Miller et al. (1978), Hall (1987), Hall and Mothes 2007; Hall and von Hillebrandt (1988), Mothes et al. 1998; Mothes (1992), which have both described previous eruptive behavior, and likely future forms of activity. In their recent study, Pistolesi et al. (2011:2) cross-checked historical accounts with the physical evidence of deposit features to develop a timeline of recent eruptions, asserting that there is strong evidence of eruptions in 1534, 1742, 1744, 1766, 1768, 1803, 1853, 1877 , and 1880. In addition, they have located historical accounts of other eruptive events, though without apparent supporting geological evidence in (1757-1758, 1857, $1866,1885,1903-1904,1906,1912,1942)$. There is a broad scientific consensus that the volcano is active, with Pistolesi et al. (2011) asserting that it remains one of the most active volcanoes on the planet. This history of activity has been represented as a frequency over the past 2,000 years of at least one VEI $\geq 3$ eruption every 117 years (Barberi et al. 1995; Hall and Mothes 1995). Of course such assertions are descriptive of past episodes, and do not necessarily represent future activity. This uncertainty of future behavior is reflected in studies that argue that the lack of a clear pattern of type of behavior makes the volcano more, not less dangerous. "An important result from the perspective of volcanic hazards is our conclusion that, over the studied period, no clear relation exists among repose time, eruption magnitude, and magma composition (Pistolesi et al. 2011: 1)." This lack of predictability, combined with concerns of a potential increase in activity in 2001, prompted the government of Ecuador to commence disaster management plans related to Cotopaxi.

Based on analysis of deposits in the Volcano's drainage systems, previous eruptions have all generated lahars (Ettinger et al. 2007; Humboldt 1810; Sodiro 1877; Wolf 1878; Hall et al. 2005). With a peak at 5,897 m, Cotopaxi is glaciated, with an estimated $14 \mathrm{~km} 2$ of coverage, with a total volume of around $0.5 \mathrm{~km} 3$ (Ettinger et al. 2007; Ramirez et al. 2004). While the glacier appears to be receding, it still represents a significant potential for the generation of a lahar. Previous lahars from Cotopaxi have caused significant devastation to communities in its path. The first written record of a village being buried by the Volcano comes from 1555 where Agustín de Zárate (1555) reported that a village, "la Contiega" was consumed by a lahar. During the last major eruption, in 1877, lahar deposits have been identified as far away as Esmeraldas, on the Pacific coast $(320 \mathrm{~km})$ from Cotopaxi.

Analysis in the Northern drainage system has shown a deposit depth of over 12 feet in the towns of Sangolqui and San Rafael, which are some $40 \mathrm{~km}$ away from the foot of Cotopaxi. Recent excavations in the built up area of these towns to construct a highway overpass provide stark evidence of the past impact of lahars on this particular region. Some analysts assert that simulations suggest that a major eruption is likely to result in a total volume of $2 / 3$ of what was experienced in 1877 due to a reduced glacial coverage (Aguilera et al. 2004). The apparent reactivation of the volcano in 2001 prompted a re-examination of the threat from the volcano, resulting in the issuing of new lahar hazard maps by the Instituto Geofisico. There has also been significant investment in monitoring technology around Cotopaxi to provide, ideally, advanced warning of volcanic hazards.

Over the past 50 years this region has become a suburb of Quito, the Ecuadorian capital, and has experienced rapid population and infrastructure growth near and in some instances physically straddling the Chillos river. While the town officials have been publishing hazard maps, this has not been accompanied by planning regulations to limit construction within the zones identified as being high-risk. Indeed a quick drive along the river system finds numerous schools and malls adjacent to the river. These have been built with both public and private capital. Members of the Instituto Geofisico indicated in private that the municipality has been encouraging greater growth in the region to increase the tax-base.

According to Hall and Mothes (1997) and Mothes et al. (1998), if an eruption were to occur at present some 80,000 people may be at risk. Population growth has continued apace since the mid-1990s, with increasing population densities throughout the potentially affected region. The growth of population in the high risk zones increases the potential loss of life from any lahars that might reach San Rafael and Sangolqui. At the same time, the impact of the increased number of buildings and other manmade infrastructure in the Chillos valley has not been extensively modeled.

To manage a potential lahar disaster the government of Ecuador has focused on preparing for an evacuation. ${ }^{2}$ Initially this entailed identifying evacuation routes, safe havens, erecting signs throughout the areas identified as 'high risk', publishing the geological hazards maps, and conducting outreach within the high-risk zones. There were plans, which have since been shelved, to erect a network of sirens throughout the region to communicate with the population in an emergency.

\section{Methods}

Shifting analysis to insecurities of local populations, and to their narratives of trust in relationship to these broader concerns, has required an approach that is distinct from the usual focus on understandings of a singular natural hazard. The analysis requires, in the first instance, the identification of local narratives of what 
threatens and/or undermines the pursuit of a good life. Following this, the level of trust with respect to opinion leaders in general needs to be determined. It is only after this general analysis of insecurity is conducted that it makes sense to turn to the issue of the specific natural hazard. In this way we can see the conceptual terrain within which individuals and communities understand particular hazards, and are better able to provide policy recommendations. What follows is a discussion of the application of this approach to understand the narratives of insecurity amongst peoples living within a zone declared to be at a high-risk from lahars generated on the slopes of the Cotopaxi volcano in Ecuador.

To explore the narratives of insecurity, and the extent of trust in security actors in relation to volcanological hazards, this study commenced with a review of the general political, economic, and crime environment in Ecuador, as well as the social volcanology that has focused on Ecuador (Lane et al. 2003; Tobin et al. 2002; Metzger et al. 1999). This was followed up with informal interviews with members of the Instituto Geofisico, in Quito, to refine the survey, and to test the questions. In particular the list of opinion makers, people and institutions expected to impact on individuals' perceptions and decision making in relation to a natural hazard, was narrowed to a list of ten. The decision was made to concentrate interviews within a geographic zone identified in the Instituto Geofisico's hazard maps as being in a high-risk zone from lahars. This choice was in large part driven by the interests of the Instituto in whether previous communication strategies had raised scientific awareness of the volcano. While this has meant that the findings are restricted to a narrow population base, the project's funding was derived from a study of the hazards posed by the Cotopaxi volcano. This has allowed a focus on the question of how the assumed risk posed by a natural hazard, a lahar (according to the hazard maps published by the Instituto Geofisico), is perceived in the community, and how it relates to broader perceptions of insecurity.

This paper is based on the interviews that were conducted in San Rafael and Sangolqui in August 2012. These interviews involved both closed and open-ended questions to gauge participants' understandings of the threats posed by Cotopaxi, and their awareness of existing disaster management plans. At the same time the interviews included questions to assess the general security concerns of participants, as well as their levels of trust and confidence in a range of authority figures. Multiple questions were asked on each of the research themes to provide confidence in the responses. The questionnaire included Likert scales (Likert 1932) that were then compared to narrative responses on open-ended questions. During the field work, 158 interviews were conducted, with each generally taking $25 \mathrm{~min}$ to complete. ${ }^{3}$ These were conducted in Spanish through a translator who was familiar with the local context, as well as the technical language of volcanology.

To assess levels of trust, respondents were asked to rank ten opinion makers in terms of whom they trusted the most to least. Later in the interview, following detailed questions relating to perceptions of volcanological hazards and risks, respondents were asked to rank the same opinion makers specifically in relation to a potential volcanological disaster. Demonstrating the change in ordinal rankings is difficult given that the difference between any two rankings is unlikely to be consistent for one respondent, let alone between respondents. Figs. 3 and 4 show the number of rankings provided to each opinion maker in relation to general trust (Fig. 3) and in relation to volcanic risks (Fig. 4), the final column indicates how often respondents stated they had no trust in the particular individual or organization. ${ }^{4}$

Participants were selected through a non-random purposive targeting of small businesses and houses in the high-risk zones in Sangolqui and San Rafael. Interestingly, and as will be discussed in more detail shortly, much of the housing in this area was for middle, and upper-middle class earners. The result is that there were numerous gated communities that were difficult to access. Furthermore, many of the residences in the area are for people commuting to Quito. This posed difficulties in collecting responses from a representative sample of the community. A high percentage of the respondents were working in small businesses along the high-streets in the high-risk zones. This is reflected in a disproportionate representation of female respondents (Fig. 1). Interestingly, the breakdown of the education of participants was more representative that was expected.

Given the number of interviews, the findings are not being used to provide a generalized claim of Ecuadorian perceptions/beliefs, nor is this the intent of the research. Rather, the findings are being used to point to the ways in which individuals in the high-risk zone articulate their security concerns, and how they see the threat of a volcanic eruption relating to the broader sources of insecurity.

\section{Results and discussion}

\section{Context of insecurity}

Within Ecuador there are two broad contexts of insecurity that need to be taken into account. The first is that the Inter-Andean valley is an area of significant volcanic and seismic activity. Ecuadoreans are surrounded by active volcanoes, and there have been numerous dramatic eruptions in the past decade, dislocating thousands of peoples. As such, Ecuadoreans have a local frame of reference to consider the risks, and the potential impacts, posed by volcanic eruptions. As will be shown, while interviewees living in the high-risk zone may have a poor technical knowledge of the particular natural hazards 
facing Sangolqui and San Rafael, they nevertheless had a sound grasp of the range of effects likely to accompany a major eruption. Yet, at the same time people are evidently willing to live in areas they know as being listed as being at high risk from volcanic hazards, and have often chosen to move into the area when they have the financial capacity to live elsewhere. It is a broader focus on insecurity that provides a compelling narrative of the choices people make. While vulnerability highlights structural and cultural dynamics that may increase exposure to risk, it is not as effective in highlighting the lives people wish to live. A human insecurity approach helps to contextualize what people living in natural hazard zones see as the threats to their pursuit of a dignified life, in order to help understand why they choose (where they have options) to live with hazards.

The second issue is that the recent political history of Ecuador is marked by numerous non-democratic transfers of power from one regime to the next, and the military has played a central role in these changes of governance when they have publicly declared their withdrawal of support from one regime or the next since 2000. Ecuador also faces allegations of endemic corruption. The Corruption Perception Index (CPI), currently scores the country 2.7 out of a possible 10 (where 10 indicates a very clean state). This places Ecuador in a tie for the $120^{\text {th }}$ position globally, in a group with Iran, Ethiopia, Guatemala and Mozambique. In addition to the level of corruption, there are concerns with the ability of the media to undertake its responsibilities to the general population. Human Rights Watch has reported that the government of President Rafael Correa introduced legislation to constrain the press, and to allow for the dismissal of judges (HRW 2012). It further reports that "[i]mpunity for police abuses is widespread and perpetrators of murders often attributed to a "settling of accounts" between criminal gangs are rarely prosecuted and convicted (HRW 2012)". This context is of direct relevance in seeking to understand local responses to experts and in particular groups connected with the Government. This is particularly crucial to disaster management as this suggests that any claims that Cotopaxi might represent a threat will be assessed by the public in the context of broader perceptions of the trustworthiness of the institutions. This may also impact on the likely engagement and cooperation with government disaster management teams. In particular, this history and data suggests that police, military, and government officials are unlikely to be seen as neutral and reliable.

These observations highlight a basic premise of this paper, and one that was born out in the interviews. In seeking to understand the nexus between awareness of the volcanic hazards, the trust in public officials and the media, and the decisions of peoples to live with apparent natural hazard risk, we must root our analysis within an appreciation of the relations of power within local society, and the extent to which the governing structure is seen as legitimate. Furthermore, within spaces perceived as being at risk, and where people perceive themselves living with significant levels of insecurity on a daily basis, the question of whether they have an accurate scientific knowledge of volcanic activity is not sufficient.

\section{Awareness of specific geological hazards}

As was stated, technocratic studies of risk perception surrounding natural hazards - and volcanic hazards specifically - commence with an analysis of the ability of local people to accurately describe the volcanic threat. Representatives of local disaster management teams stated before we conducted interviews that we would find that people do not know about the volcanic risk, and that people do not think an eruption will happen in their lifetime (interview A, 15 June 2012; interview B, 15 June 2012). This was accurate to a point, as individuals were seldom able to describe volcanic processes, or the precise threats posed by Cotopaxi, in a manner that is consistent with scientific understandings. Certainly the later was true to a large extent, with individuals often stating that they did not think an eruption was likely.

The local knowledge in the target communities of the nature of the threats from Cotopaxi was partial in terms of 'scientific accuracy' from a geological science standpoint. The focus on lahars was striking in this respect. As lahars represented the most direct volcanic hazard to the communities targeted for interviews, the survey posed a number of questions on the topic. The term itself is a technical one, and is not widely understood, even though it is often used by policy makers and technical advisors in Ecuador. As such, while the first question sought to understand the breadth of understanding of this particular term, when respondents did not recognize it, the phenomenon was described prior to subsequent questions. Respondents regularly understood what this process was, labeling it a mud-slide or flood.

Q. 15 Do you know what a lahar is?, with a follow-up question asking the respondent to describe a lahar if they answered yes.

Q. 17 On a scale of 1 to 10 , where 1 means never, how likely do you think it is that this village will be affected by a lahar?

Q. 27 Do you know if there are any evacuation shelters or evacuation routes for you to use in the case of a volcanic emergency?

Q. 28 Do you know the warning signal for a lahar?

In addition there were questions asking the respondent to rate the threat to the community from a number of hazards associated with volcanoes. 
When asked to rank the level of danger associated with hazards from Cotopaxi to their community (roughly $40 \mathrm{~km}$ from the base of Cotopaxi), over $75 \%$ of respondents indicated that lava was the most serious threat - described as hot molten rock - followed by flying debris, and ash clouds. In contrast, lahars were routinely listed as the least serious threat. Taken alone this may be deeply troubling. However, at the same time, lahars were still seen as a danger (just less so than those threats embedded within the popular imaginary). Additionally, individuals did indicate that the volcano, if it erupted, would be devastating to their communities.

"This community would be ruined because we are so close to Cotapaxi... I know the risk is by the rivers (Interview 8)"

"The elders have told me that when Cotopaxi erupted this whole areas was affected (Interview 9)."

$$
1
$$

"At the school they told us about it. They told us how long ago it erupted, and that it is a very dangerous volcano, and that it is one of the largest volcanoes in Ecuador (Interview 82).”

\section{If it erupts "nothing would be left (Interview 36)."}

That said, there was a general lack of technical knowledge about the hazards associated with volcanic unrest. As was argued, if we assume that peoples' reactions to a potential emergency is directly related to their extent of knowledge of the risks, then these findings would suggest a likely low level of compliance. Yet, it is entirely different to conclude that this lack of awareness reflects a lack of concern, or an unwillingness to comply with emergency orders. Indeed, the respondents overwhelmingly stated they would comply with an evacuation order. In a few interviews, people actually identified a color-coding system to the emergency preparedness plan, and many individuals talked about the marked evacuation routes.

Perhaps more concerning to disaster managers is that numerous respondents indicated that as they could physically see the volcano they could ascertain the danger themselves. "Since we can see Cotopaxi all the time we are checking on it" (interview 2). If one works from the techno-scientific standpoint this is deeply concerning, and likely serves to reinforce the general lack of faith in the knowledge of lay persons. As risk mitigation behavior is seen as deriving (for many academics and policy makers) from the accurate understanding of the threat, this raises the specter of communities refusing to take action in the case of a warning. There is, however, a range of other ways to interpret these findings that result in entirely different conclusions. First, while the specific geo-physics of volcanic activity may be unclear to the respondents, there was still a broad awareness that Cotopaxi is a volcano, that it is still active, and that some form of eruptive behavior is possible. More importantly, there was a clear sense running through the interviews that people have not paid much attention to the volcanic hazards as they have not been told that a risk is imminent or likely within a fixed period of time. When a priest in the local area was interviewed, he was asked if he talked to his congregation about the volcano and he said he did. But he said "they don't care about these issues. They are taking care of their daily lives (Interview 52)."

This can be analyzed in two distinct ways. The traditional 'scientific realism' approach would seek to assess the perception gap, and would tend to focus upon the lack of accurate grasp of the volcanic risk. A study so focused would then proceed to assess what is interfering with an objective understanding of the hazard. The second form of analysis, and the one that this study highlights as essential, is to focus upon how perceptions of risk are not 'objective', and are contextualized within their everyday lives. Once again we return to the manner in which the perceptions of the volcanic risk are

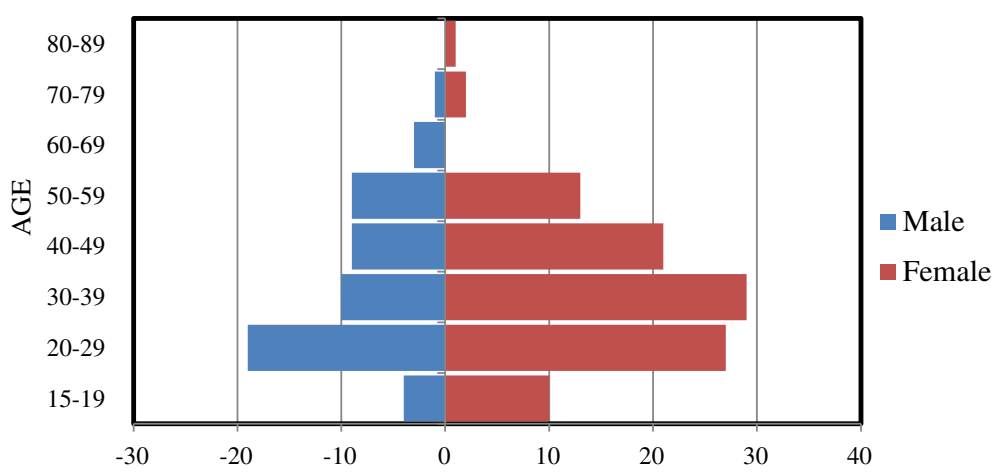

Fig. 1 Demographics of respondents 
fundamentally socio-political. Interviewees did not generally deny the possibility of an eruption (there were a few outliers), rather they demonstrated a consistent lack of concern for distant threats when peoples' lives are contingent in the short to medium term. Despite an awareness of the geological processes at play, people recognized there were risks associated with living in the area, and were sufficiently informed of the threat in comparison with more systemic and consistent threats to their daily lives. The choice to live in an area identified as being at high risk from lahars makes sense when we see it in relationship to the other concerns in their daily lives.

\section{Perceptions of insecurity}

The focus on insecurity highlights that people are much more concerned with threats perceived as proximate to their daily lives. This does not mean that people would ignore warnings if they were given, or evacuation orders if they were issued. Indeed despite the lack of technical knowledge, and the very low ranking of the volcano in their rankings of sources of insecurity ( $94 \%$ of respondents stated that the volcano was not a daily concern), when asked if they would evacuate if told to do so, the adherence rate was remarkably high (81\%). As Colvello (1983) argued, surveys on disaster preparedness and response do a poor job of determining behavior in an actual emergency. Rather, disaster management experts tend to rely on the accuracy of local awareness of the physical processes of volcanic activity as a proxy for likely compliance with emergency plans.

However, in refocusing attention on the question of security concerns, an entirely different set of conclusions are arrived at. As Fig. 2 indicates, only $6 \%$ listed Cotopaxi amongst their top ten security concerns. Natural disasters, which included earthquakes, floods, and droughts, and climate change, accounted for another $6 \%$. To begin with this indicates that the lack of concern with the Volcano is not primarily a result of ignorance about Cotopaxi. Rather, observers consistently argued that their relatively low ranking for the Volcano was a

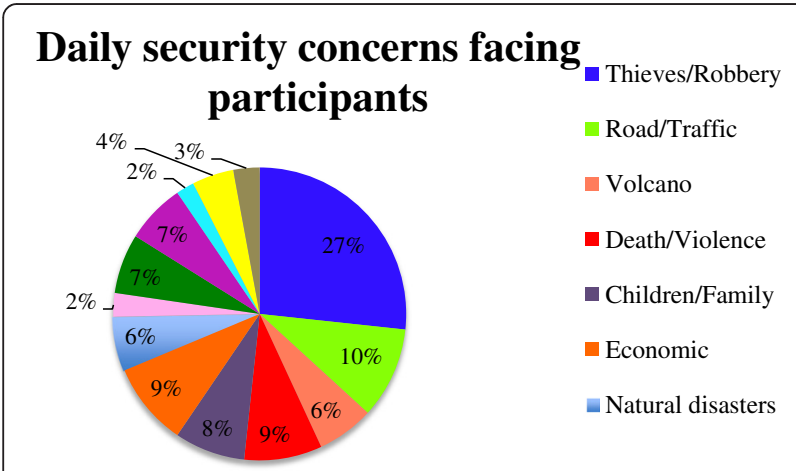

Fig. 2 Daily security concerns facing participants direct result of other concerns impacting on their lives on a daily basis.

"This is not a safe country (Interview 47)"

When asked how often she worries about being robbed one woman said "All the time! Just leaving this building puts me at risk (Interview 26)"

\section{"Security is a big concern, thieves,} transportation...(Interview 81)" When asked about the volcano she said "right now I'm not concerned about it because it is not erupting... When we hear about other volcanoes erupting, that is when I get concerned."

"We have many problems all around us: robbery, stealing, in work and at home (Interview 7)"

Security is "to walk peacefully on the street. The Volcano is not very important as it isn't an emergency right now (Interview 70)"

The markers of an insecure environment are prevalent in Quito and its environs. There are armed guards outside of most large places of business, armored cars can be commonly found on the streets, and in popular outdoor venues police are everywhere. The concern of crime was constantly being reinforced by during our own stay in Quito, with our Ecuadorian counter-parts warning us of walking outdoors at night, of the risk of theft on public transport, and of being cautioned against visiting various neighborhoods alone during the day. While purely random, the lead author of this paper watched two day-light muggings during his brief research trip to Quito, which served to drive home the common message that came up in nearly every interview: that the danger to peoples' lives consistently emanates from crime, poor health, job insecurity and traffic accidents. The prioritizing of such day-to-day threats is not only understandable, but also entirely coherent.

While the interviews took place in zones identified as being at risk from lahars, the area was considered by locals as being of lower risk for those concerns which dominate their perceptions of security. Indeed, there were a large number of families that had moved into the area knowing that it was at risk from lahars. Though a number of the people interviewed indicated that they worry about being robbed on the street in the interview zones, there was also a commonly expressed view that it was better than Quito, and that the threat of crime had decreased over the past few years. As one individual stated succinctly: "[t]his place is safer than Quito (Interview 12)". This puts an entirely different light on the usual framing of the issue which is 
typically expressed as 'why are people willing to live with risk'? What the framing of insecurity provides is an insight into this issue, that people see living in this particular natural hazard zone as contributing to a better quality of life, providing for greater human security.

\section{Trust in opinion makers and security implementers}

Related to the issue of insecurity, the focus on security discourse and practice demands a consideration of the ways in which the broader security apparatus of the state is perceived. If, as has been shown in the interviews, there is a prioritization of security concerns according to what threats are most proximate, then the issue of trust in the government should be related to this framing. Indeed, this was born out in the interviews where the majority of participants indicated that they placed the most trust in their family. Against a backdrop of an insecure state, where police are not trusted to prevent crime, and government officials are often not expected to work in the interests of communities, respondents indicated that they have a very low level of trust in government representatives.

"I don't trust anyone else but the family. They just talk, tell us about what they'll do and do nothing (Interview 27)"

"Thieves, police do not work well, I'm concerned that the government doesn't pay attention to the people (Interview 58)" - This man said he would evaluate the threat for himself.

One woman (Interview 37) who described how the last lahar had devastated the area, said that if she was told to evacuate she would be the last to leave. When asked why she stated that she did not trust the police, as they do not protect the area, or the government who never listened.
"I am very concerned about thieves, the authorities do nothing... I've been told to evacuate before and I

didn't... The Government would have people evacuate according to their own interests. (Interview 31)"

"Military would have to come take us away. People are worried about their things. (Interview 10)"

\section{"The military would take advantage and loot what is} left (Interview 20)."

During the interviews respondents were asked to rank a list of people in order of in whom they had the most trust. Tellingly many of the people refused to even rank most of the list, stating that they had no trust at all in the government. The following Figs. 3 and 4 show the rankings given to each of the ten opinion leaders. In terms of general trust Scientists would appear to have done well, with a mode placement of fifth. This reflects the ways in which there were wildly different rankings for the police, priests and village elders. However, as shown in Fig. 4, scientists scored exceptionally well in relation to volcanic risks. This is in contrast to the government, which uniformly scored poorly.

The responses in Fig. 3 indicate a general distrust in government institutions, and particularly in those associated with politics more broadly. In the context of insecurity this should not be surprising, and also goes some ways to explaining why people have been willing to move from larger cities to the natural hazard high risk zones of Sangolqui and San Rafael.

There was an apparent disparity between the ordinal rankings assigned to the police, and the qualitative comments made repeatedly about how the police were not to be trusted. This is partially explained by the nature of ordinal rankings. Indicating that the police are more trust-worthy than the government or mayor does not

\begin{tabular}{|c|c|c|c|c|c|c|c|c|c|c|c|c|}
\hline & \multicolumn{11}{|c|}{ Ranking } & \multirow[b]{2}{*}{ Total } \\
\hline & 1 & 2 & 3 & 4 & 5 & 6 & 7 & 8 & 9 & 10 & $\begin{array}{r}\text { No } \\
\text { Trust }\end{array}$ & \\
\hline \multirow{3}{*}{$\begin{array}{l}\text { Elders } \\
\text { Family }\end{array}$} & 7 & 28 & 19 & 9 & 13 & 7 & 7 & 7 & 9 & 21 & 25 & 152 \\
\hline & 108 & 11 & 5 & 4 & 2 & 1 & 2 & 3 & 6 & 3 & 7 & 152 \\
\hline & 3 & 18 & 11 & 8 & 16 & 11 & 11 & 19 & 18 & 14 & 23 & 152 \\
\hline Media & 4 & 16 & 11 & 16 & 17 & 16 & 7 & 15 & 12 & 18 & 20 & 152 \\
\hline Police & 4 & 16 & 25 & 20 & 21 & 7 & 9 & 12 & 10 & 12 & 16 & 152 \\
\hline Government & 5 & 7 & 12 & 13 & 14 & 19 & 11 & 14 & 9 & 25 & 23 & 152 \\
\hline Scientists & 12 & 14 & 20 & 17 & 12 & 19 & 18 & 5 & 6 & 7 & 22 & 152 \\
\hline Mayor & 3 & 4 & 6 & 6 & 15 & 18 & 25 & 17 & 22 & 13 & 23 & 152 \\
\hline $\begin{array}{l}\text { Civil } \\
\text { Defence }\end{array}$ & 10 & 17 & 11 & 16 & 12 & 15 & 14 & 16 & 10 & 5 & 26 & 152 \\
\hline Military & 5 & 7 & 14 & 12 & 10 & 16 & 14 & 15 & 14 & 17 & 28 & 152 \\
\hline
\end{tabular}

Fig. 3 Ranking of general trust in opinion makers 


\begin{tabular}{|c|c|c|c|c|c|c|c|c|c|c|c|c|}
\hline & \multicolumn{11}{|c|}{ RANKING } & \multirow[b]{2}{*}{ Tota } \\
\hline & 1 & 2 & 3 & 4 & 5 & 6 & 7 & 8 & 9 & 10 & $\begin{array}{r}\text { No } \\
\text { Trust }\end{array}$ & \\
\hline Elders & 17 & 13 & 5 & 7 & 7 & 5 & 6 & 13 & 18 & 47 & 18 & 156 \\
\hline Family & 7 & 7 & 9 & 7 & 19 & 10 & 12 & 22 & 31 & 13 & 19 & 156 \\
\hline Priest & 3 & 9 & 5 & 4 & 6 & 5 & 8 & 30 & 29 & 33 & 24 & 156 \\
\hline Media & 11 & 20 & 22 & 14 & 15 & 16 & 20 & 13 & 7 & 5 & 13 & 156 \\
\hline Police & 4 & 6 & 10 & 21 & 17 & 30 & 19 & 12 & 12 & 8 & 17 & 156 \\
\hline Government & 10 & 19 & 16 & 28 & 16 & 15 & 15 & 8 & 3 & 7 & 19 & 156 \\
\hline Scientists & 107 & 12 & 5 & 7 & 5 & 5 & 3 & 3 & 3 & 5 & 1 & 156 \\
\hline Mayor & 5 & 7 & 12 & 17 & 28 & 18 & 23 & 16 & 9 & 4 & 17 & 156 \\
\hline $\begin{array}{l}\text { Civil } \\
\text { Defence }\end{array}$ & 21 & 45 & 21 & 10 & 13 & 12 & 6 & 5 & 1 & 5 & 17 & 156 \\
\hline Military & 7 & 17 & 32 & 14 & 18 & 22 & 11 & 5 & 4 & 6 & 20 & 156 \\
\hline
\end{tabular}

Fig. 4 Ranking of trust of opinion makers in relation to volcanic hazards

mean that people trust the police, rather the finding is more narrowly constrained, indicating that the police are deemed more trustworthy than other opinion makers and security institutions. We can also speculate that the failure of the police to take action in relation to crime is perceived as relating to a lack of capacity, rather than distrust in the police. ${ }^{5}$

Elders were often scored quite lowly, which is likely explained by the lack of a role for the elders in modern urban settings. Interestingly, more individuals ranked elders first in relation to volcanic emergencies than in general levels of trust, which may point to a belief that their personal memories may provide insight into how to respond to a volcanic emergency.

When it came to the ranking of scientists in terms of trust, there was a dramatic shift between the everyday, and in relation to a potential volcanic emergency. As Fig. 3 shows, their distribution in the ordinal rankings were fairly evenly distributed between the third and seventh rank (with a mode of third place). However, when people were asked who they would trust in relation to information and advice in relation to volcanic events, scientists came out at the top of the list with $66 \%$ of respondents ranking scientists as the most trustworthy. This suggests that on the one hand scientific expertise is not always seen as relevant to peoples' daily lives, but on the other that they do see expertise as having a role in particular circumstances.

This study has highlighted how a focus on local narratives of insecurity provides a useful addition to the literatures on vulnerabilities and disasters. First, by privileging local narratives and experiences it serves to de-center the concerns of technical elites charged with the management of natural hazards. While people broadly understood that Cotopaxi presented a potential risk, the awareness of the specific nature of the danger was limited. DRR policy makers that ascribe to the notion that a scientifically correct understanding of hazards is highly desirable, if not essential, would likely derive from this that compliance with emergency preparedness and response may be negatively impacted. Yet, as our interviews demonstrated most people indicated that they would comply with a call to evacuate.

In so doing the lived experiences of peoples in communities exposed to natural hazards are emphasized. This in turn enables us to understand the broader context within which decisions about living with hazards are made. While the vulnerabilities literature highlights the ways in which cultural and structural elements, such as poverty, gender, and ethnicity impact on the exposure to hazards, it does not always foreground the local narratives of insecurities. As has been shown in the case of urban life North of Cotopaxi, people can opt to live with natural hazards when it is seen as posing a less imminent threat than other components of their lives (such as crime). This should be seen as an addition to the vulnerabilities approaches rather than a replacement.

In terms of the policy implications, an insecurity approach suggests that DRR strategies need to be contextualized with the perceptions of locals. If the communication strategies related to disaster preparedness ignore the everyday perceived risks they may ring hollow for the targeted populations, and undermine the confidence that they have in the broader disaster response architecture of the state.

Furthermore, given the general trust that was accorded to scientists with respect to volcanic hazards, the role in the scientific community in communicating the risk is likely to be essential. The findings also suggest that the drive to communicate DRR strategies to communities needs to be focused upon building and maintaining trust between communities and technical experts. This does not mean that communicating about geological processes is not necessary, but rather the 
impetus in such activities should largely be about building community trust in the volcanic hazard management system. This is significant as it would necessarily alter the communication plan, and the subsequent assessment of its effectiveness.

The fieldwork has also highlighted a largely unforeseen dilemma in the management of natural hazards in Ecuador. The respondents to the surveys tended to assume that the scientists were disconnected from the subsequent management of disasters, and were removed from the government, which was reflected in the very different scores on trust accorded to them. At the same time respondents regularly stated in the interviews that they desired more regular visits by scientists and that they would like to learn more about Cotopaxi. The complexity arises in the ways in which this may result in a greater awareness of the links between the Instituto Geofisico in Quito and the local and federal levels of government. It is unclear whether this would improve the standing of the disaster management officials and the police, or whether this would instead erode the trust currently in the scientific community. This observation has arisen precisely because the analysis took on a general analysis of insecurity, rather than focusing exclusively on the volcanic risk.

\section{Conclusions}

Risk is not an objective phenomenon, but must be understood as deeply socio-political. While the volcanic event itself is a result of complex geophysical events, and our ability to predict phases of unrest may improve, the risk of events to the societies themselves are inseparable from social practices. Risk inherently requires calculations of value, which are inherently political. Furthermore, peoples' perceptions of an event itself are also culturally constituted. Yet, the language of risk permeates the entirety of the literatures on the interactions of volcanic systems and human populations. While it is possible to reconfigure or re/develop a definition of risk that is not 'objective', in a positivist sense, and that accounts for social differentiation and relations of power, such an endeavor would be forced to confront the dominant scientific and actuarial narratives. As has been argued here, and has been supported by empirical observation of populations in Ecuador, the application of a risk framework forces a focus on a singular threat. In turn this drives a discourse that those who do not react in an assumed logical fashion in relation to the threat are somehow failing to grasp the precise nature of the threat.

To come to an understanding of the socio-political dynamics informing peoples' narratives and practices in relation to natural hazards, this paper has advanced the argument that an ideal starting position is to decenter the specific geophysical hazard, and commence with peoples' perceptions of insecurity more broadly. Drawing on critical security studies, this analysis has shown that peoples' understandings of natural hazards are inherently constructed in relation first to what they perceive as a good life, and secondly in relation to other perceived sources of insecurity. In the case of the people that were interviewed in the course of fieldwork for this study, people indicated that for most of their identified sources of insecurity the risk was exceptionally high on a day-to-day basis, and that they would have no warning of when robbery, kidnapping, or a serious accident might occur. As such, the concern over a potential event in the medium to long term simply did not rate as a serious concern.

\section{Endnotes}

${ }^{1}$ This is not constrained to social volcanology, and as Donovan et al. show, "...scientists are interested in the wider context in which they operate and the social implications of their work (Donovan et al. 2012: 1014)."

${ }^{2}$ For a discussion of how the Ecuadorian government (both state and municipal level) responded to a prior potential disaster in Quito refer to Metzger et al. 2000.

${ }^{3}$ Copies of the questionnaire are available from the study's lead author at: Ryerson.christie@bristol.ac.uk.

${ }^{4}$ Spearman's Correlation Coefficient (SCC) was run against each pairing of trust in opinion makers. The results have not been included here as the only pairing, between trust in government and trust in the mayor in relation to volcanic emergencies showed a significant correlation, SCC of .52, and 2 tailed significance of .00 . The complete tables are available from the lead author.

${ }^{5}$ Follow-up questions related to the level of trust accorded to each opinion maker were not feasible. This would have required a substantially longer interview process and would have run the risk of exhausting the patience of respondents.

\section{Competing interests}

The authors declare they have no competing interests.

\section{Authors' contributions}

$\mathrm{RC}$ is the lead author and was involved in the project design, data gathering and interpretation. OC was involved in data collection in Ecuador, and in subsequent statistical analysis of the findings. JG. was involved in project design and management, and in the review of the geological literatures. All authors read and approved the final manuscript.

\section{Acknowledgments}

The support of the Instituto Geofisico was invaluable in the completion of this research. Patty Mothes and Mario Ruiz were instrumental in facilitating the fieldwork and provided valuable logistical support. This project was funded by a grant from the European Commission (FP7-ENV-2011: "VUELCO" under contract \#282769). 


\section{Author details}

${ }^{1}$ School of Sociology, Politics and International Studies (SPAIS), University of Bristol, Bristol BS8 1TU, UK. ${ }^{2}$ School of Earth Sciences, University of Bristol, Bristol BS8 1RJ, UK.

\section{Received: 28 November 2014 Accepted: 29 September 2015} Published online: 08 October 2015

\section{References}

Adams J (1995) Risk. UCL Press, London

Aguilera E, Pareschi M, Rosi M, Zanchetta G (2004) Risk from Lahars in the Northern Valleys of Cotopaxi Volcano (Ecuador). Nat Hazards 33(1):161-1189 Alexander D (1993) Natural Disasters. Kluwer, London

Alexander D (1997) The study of natural disasters 1977-1997: Some reflections on a changing field of knowledge. Disasters 21(4):284-304

Alexander D (2002) From civil defence to civil protection - and back again'. Disaster Prevention and Management 11(3):209-13

Allen K (2006) Community-based disaster preparedness and climate adaptation: Local capacitybuilding in the Philippines. Disasters 30(1):81-101

Bankoff G (2001) Rendering the world unsafe:'vulnerability' as western discourse. Disasters 25(1):19-35

Bankoff G, Frerks G, Hihorst D (eds) (2004) Mapping Vulnerability: Disasters, Development and People. Earthscan, London

Barberi F, Coltelli M, Frullani A, Rosi M, Almeida E. (1995) Chronology and dispersal characteristics of recently (last 5000 years) erupted tephra of Cotopaxi (Ecuador): implications for long-term eruptive forecasting. J Volcanology and Geothermal R 69(3-4): 217-239

Barclay JK, Haynes T, Mitchell C, Solana R, Teeuw A, Darnell H, Crosweller P, Cole D, Pyle C, Lowe C, Fearnley C, Kelman I (2008) Framing volcanic risk communication within disaster risk reduction: finding ways for the social and physical sciences to work together. Communicating Environmental Geoscience 305:163-77

Carlino S, Somma R, Mayberry G (2008) Volcanic risk perception of young people in the urban areas of Vesuvius: Comparisons with other volcanic areas and implications for emergency management. J Volcanol Geotherm Res 172:229-243

Cashman K, Cronin S (2008) Welcoming a Monster to the World: Myths, oral tradition, and modern societal response to volcanic disasters. J Volcanol Geotherm Res 176:407-418

Chester D, Duncan A, Dibben C (2008) The Importance of Religion in Shaping Volcanic Risk Perception in Italy, with Special Reference to Vesuvius and Etna. J Volcanol Geotherm Res 172:216-228

Chester DK (2005a) Theology and disaster studies: the need for dialogue. J Volcanol Geotherm Res 146:319-328

Chester DK (2005b) Volcanoes, society and culture. In: Marti J, Ernst GJ (eds) Volcanoes and the environment. Cambridge University Press, Cambridge

Chester DK, Dibben C, Coutinho R, Duncan AM, Cole PD, Guest JE, Baxter PJ (1999) Human adjustments and social vulnerability to volcanic hazards: the case of Furnas Volcano, São Miguel, Açores. Geol Soc Lond Spec Publ 171:179-188

Christie R (2010) Critical voices and human security: to endure, engage or critique. Security Dialogue 41(2):169-190

Christie R (2008) The human security dilemma: lost opportunities, appropriated concepts or actual change? In: Kepner W, Liotta PH (eds) Environmental change and human security:recognizing and acting on hazard impacts. Springer, Dordrecht

Colvello V (1983) The perception of technological risks: a literature review. Technol Forecast Soc Chang 23(1):285-297

Comfort LK (2012) designing disaster resilience and public policy: comparative perspectives. J Comparative Policy Analysis 14(2):109-113

Cordona $\mathrm{O}$ (2003) The need for rethinking the concepts of vulnerability and risk from a holistic perspective: A necessary review and criticism for effective risk management. In: Bankoff G, Frerks G, Hillhorst D (eds) Mapping vulnerability: disasters, development and people. Earth Scan Publishers, London

Cronin SJ, Gaylord DR, Charley D, Alloway BV, Wallez S, Esau JW (2004) Participatory methods of incorporating scientific with traditional knowledge for volcanic hazard management on Ambae Island, Vanuatu. Bull Volcanol 66(7):652

Cutter SL (2003) The vulnerability of science and the science of vulnerability. Annals of theAssociation of American Geographers 93(1):1-12

Cvetkovich G, Löfstedt R (1999) Social trust and the management of risk. Earthscan, London
Davis M, Ricci T (2004) Perceptions of risk for volcanic hazards in Italy: a research note. International J of Sociology and Social Policy 24(10-11):159-165

Devereux S (2001) Livelihood insecurity and social protection: a re-emerging issue in rural development. Development Policy Review 19(4):507-519

Dibben C (2008) Leaving the city for the suburbs - the dominance of 'ordinary' decision making over volcanic risk perception in the production of volcanic risk on Mt. Etna, Sicily. J Volcanol Geotherm Res 172:288-99

Dixon B, Patty J, Conte, Nagahara, J, Hodgins WK (1999) Risk Minimization and the Traditional Ahupua'a in Kahikinui, Island of Maui, Hawai'l. Asian Perspectives 38(2): 229-255

Dominey-Howes D, Minos-Minopoulos D (2004) Perceptions of hazard and risk on Santorini. J Volcanol Geotherm R 137:285-310

Donovan K (2009) Doing social volcanology: exploring volcanic culture in Indonesia. Area 42(1):117-126

Donovan KHM (2010) Cultural vulnerability in volcanic regions: an Indonesian Case Study. Ph.D. Thesis, University of Plymouth, Plymouth

Dove MR (2008) Perception of volcanic eruption as agent of change on Merapi volcano, Central Java. J Volcanol Geotherm Res 172:329-337

Enarson E, Meyreles L (2004) International perspectives on gender and disaster: differences and possibilities. International J of Sociology and Social Policy 24(10/11):49-93

Ettinger S, Mothes P, Paris R, Schilling S (2007) The 1877 lahar deposits on the eastern flank of Cotopaxi volcano. Géomorphologie: relief, processus, environnement 3:271-280

Fischhoff B, Slovic P, Lichtenstein S, Read S, Combs B (2000) How safe is safe enough? A psychometric study of attitudes toward technological risks and benefits. In: Slovic P (ed) Risk Perception. Earthscan, London

Fothergill A, Peek L (2004) Poverty and disasters in the United States: A review of recent sociological findings. $N$ Hazards 32:89-110

Gaillard J-C (2010) Vulnerability, capacity and resilience: Perspectives for climate and development policy. J of International Development 22:219-32

Gaillard J-C (2008) Alternative paradigms of volcanic risk perception: the case of Mt. Pinatubo in the Philippines. J Volcanology and Geothermal R 172(3-4):315

Gaillard J-C (2007) Resilience of traditional societies in facing natural hazards. Disaster Prevention and Management 16(4):522-544

Gaillard J-C (2003) Territorial and ethno-cultural implications of a volcanic crisis: the case of Mount Pinatubo eruption. Alaya Kapampangan Research J 1:83-88

Gaillard J-C, Mercer J (2012). From knowledge to action: bridging gaps in disaster risk reduction. Progress in Human Geography 37(1):93-114.

Gregg C, Houghton B, Johnston D, Paton D, Swanson D (2004) The perception of volcanic risk in Kona communities from Mauna Loa and Hualālai volcanoes, Hawai'i. J Volcanol Geotherm Res 130:179-96

Hall M (1987) Peligros potenciales de las erupciones futuras del volcán Cotopaxi. Politécnica, Mon Geol 5(12):41-80

Hall M, Mothes P (2007) The rhyolitic-andesitic eruptive history of Cotopaxi volcano, Ecuador. Bull Volcanol 70(6):675-702

Hall M, Mothes P, Hidalgo S (2005) Map of Volcanic history of Cotopaxi Volcano - Ecuador. Two Separate maps. Scale 1/50 000 IGM - IG/EPN, Quito

Hall M, von Hillebrandt C (1988) Mapa de los peligros volcánicos potenciales asociados con el volcán Cotopaxi: (1) zona norte and (2) zona sur. Instituto Geofísico, Quito

Haynes K, Barclay J, Pidgeon N (2008) Whose reality counts? Factors affecting the perception of volcanic risk. J Volcanol Geotherm Res 172(3-4):259

Haynes K, Barclay J, Pidgeon N (2007) The issue of trust and its influence on riskcommunication during a volcanic crisis. Bull Volcanol 70(5):605-621

Hewitt K (1995) Excluded perspectives in the social construction of disaster. International J Mass Emergencies and Disasters 13(2):317-39

Hewitt K (1983) The idea of calamity in a technocratic age. In: Hewitt K (ed) Interpretation of calamities. The Risks and Hazards series No. 1. Allen \& Unwin Inc, Boston

Hewitt K (1997) Regions of risk: A geographical introduction to disasters. Longman, Harlow

Humboldt A (1810) Vues des cordillères et monuments des peuples indigènes de l'Amérique, 2 volumes. Imprimerie de Stone JH, Paris

Irwin A (2006) The Politics of Talk: Coming to Terms with the New Scientific Governance. Soc Stud Sci 36(2):299-320

Johnston D, Paton D, Crawford RK, Houghton B, Burgelt P (2005) Measuring tsunami preparedness in coastal Washington, United States. Nat Hazards 35:173-184

Jóhannesdóttir G, Gísladóttir G (2010) people living under threat of volcanic hazard in southern Iceland: Vulnerability and risk perception. Nat Hazards Earth Syst Sci 10:407-420 
Kerlinger FN, Lee HB (2000) Foundations of behavioral research, 4th edn. Harcourt College, Holt NY

Krause K (2004) The key to a powerful agenda, if properly delimited. Security Dialogue 35(3):367-368

Lane SN, Odoni N, Landström WSJ, Ward N, Bradley S (2011) Doing flood risk science differently: an experiment in radical scientific method. Trans Inst $\mathrm{Br}$ Geogr 36(1):15-36

Lane L, Tobin G, Whiteford L (2003) Volcanic hazard or economic destitution: hard choices in Baños, Ecuador. Environmental Hazards 5:23-34

Lavigne F, De Coster B, Juvin N, Flohic F, Gaillard J-C, Texier P, Morin J, Sartohad $J$ (2008) Peoples behaviour in the face of volcanic hazards: Perspectives from Javanese communities in Indonesia. J Volcanol Geotherm Res 172:273-287

Lindell MK (1994) Perceived characteristics of environmental hazards. International J Mass Emergency Disasters 12:303-26

Likert R (1932) A technique for the measurement of attitudes. Archives of Psychology 140:1-55

Luna E (2014) Community-based disaster risk reduction and disaster management. In: López-Carresi A, Fordham M, Wisner B, Kelman I, Gaillard J-C (eds) Disaster management: International lessons in risk reduction, response and recovery. Routledge, Abingdon

López-Vázquez E (2009) Risk perception and coping strategies for risk from Popocatépetl Volcano, Mexico. Geofis Int 48(1):133-147

McKnight RK (1977) Commas in microcosm: the movement of Southwest Islanders to Palau, Micronesia. In: Lieber MD (ed) Exiles and migrants in Oceania. The University Press of Hawaii, Honolulu, HI

Mercer J, Gaillard J-C, Crowley K, Shannon R, Alexander B, Day S, Becker J (2012) Culture and disaster risk reduction: Lessons learned. Environmental Hazards: Human and Policy Dimensions 11:74-95

Mercer J, Kelman I, Lloyd K, Suchet-Pearson S (2008) Reflections on use of participatory research for disaster risk reduction. Area 40(2):172-183

Metzger P, D'Ercole R, Sierra A (2000) Political and scientific uncertainties in volcanic risk management: The yellow alert in Quito in October 1998. GeoJ 49:213-221

Metzger P, D'Ercole R, Sierra A (1999) Political and scientific uncertainties in volcanic risk management: The yellow alert in Quito in October 1998. GeoJ 49(1):213-221

Miller C, Mullineaux D, Hall M (1978) Reconnaissance map of potential volcanic hazards from Cotopaxi volcano. USGS IMAP, Ecuador, p 1072

Mileti DS, Sorensen JH (1990) Communication of emergency public warnings: A social science perspective and state of-the-art assessment. Oak Ridge National Laboratory Rep. ORNL-6609

Mothes PA (1992) Lahars of Cotopaxi volcano, Ecuador : hazard and risk evaluation. In: McCall, Laming and Scott (ed) Geohazards - natural and man-made. Chapman and Hall, London

Mothes P, Hall M, Janda R (1998) The enormous Chillos Valley Lahar: an ash-flow-generated debris flow from Cotopaxi Volcano, Ecuador. Bull Volcanol 59:233-244

Njome M, Cheo E, Chuyong G, de Wit M (2010) Volcanic risk perception in rural communities along the slopes of mount Cameroon, West-Central Africa. J Afr Earth Sci 58:608-22

Oliver-Smith A (1996) Anthropological research on hazards and disasters. A Rev Anthropology 25:303-28

Oltedal S, Moen B, Klempe H Rundmo T (2004) Explaining risk perception: an evaluation of cultural theory. Rotunde 85

Paton D, Millar M, Johnston D (2001) Community resilience to volcanic hazard consequences. Nat Hazards 24:157-169

Paris R (2001) Human security, paradigm shift or hot air'. Int Secur 26(2):87-102

Perry RW, Lindell MK (2008) Volcanic risk perception and adjustment in a multi-hazard environment. J Volcanol Geotherm R 172:170-178

Pistolesi M, Rosi M, Cioni R, Cashman K, Rossotti A, Aguilera E (2011) Physical volcanology of the post-twelfth-century activity at Cotopaxi Volcano, Ecuador: Behavior of an andesitic central volcano. Bull Volcano 75(3):1-18. doi:10.1007/s00445-013-0698-1

Poortinga W, Bickerstaff K, Langford I, Niewöhner J, Pidgeon N (2004) The British 2001 foot and mouth crisis: a comparative study of public risk perceptions, trust and beliefs about government policy in two communities. J of Risk Research 7(1):73-90

Ramirez J, Cáceres B, Cadier E, Eissen J-P, Francou B, Maisincho L et al (2004) Determinación de espesores de hielo sobre la capa glaciar del volcán Cotopaxi (Ecuador). Resultados preliminares. Rapport IRD-INAMHI-IG-EPN, Quito, Ecuador
Siegrist M, Cvetkovich G, Roth C (2000) Salient value similarity, social trust, and risk/benefit perception. Risk Anal 20(3):353-62

Siegrist M, Earle T, Gutscher H (2003) Test of a trust and confidence model in the applied context of electromagnetic field (EMF) risks. Risk Anal 23(4):705-716

Sjöberg L (2000) Factors in risk perception. Risk Anal 20(1):1-11

Slovic P (2000) The perception of risk. Earth Scan, London

Slovic P, Finucane ML, Peters E, MacGregor DG (2004) Risk analysis and risk as a feeling: some thought about affect, reason, risk and rationality. Risk Anal 24(2):311-3221

Sodiro L (1877) Relacion sobre la erupcion del Cotopaxi acaecida del dia 26 de junio, 1877. Imprenta Nacional, Quito

Thomas N, Tow W (2002) The utility of human security: sovereignty and humanitarian intervention. Security Dialogue 33(2):177-192

Tobin G, Whiteford L, Jones E, Murphy A, Garren S, Vindrola Padros C (2011) The role of individual well-being in risk perception and evacuation for chronic vs. acute naturalhazards in Mexico. A Geography 31:700-11

Tobin G, Linda A, Whiteford M (2002) Community Resilience and Volcano Hazard: the eruption of Tungurahua and Evacuation of the Faldas in Ecuador. Disasters 26(1):28-48

Toya H, Skidmore M (2014) Do Natural Disasters Enhance Societal Trust? KYKLOS $67(2): 255-279$

van der Pligt J (1996) Risk perception and self-protective behavior. Eur Psychol 1(1):34-43

van Manen SM (2014) Hazard and risk perception at Turrialba Volcano (Costa Rica); implications for disaster risk management. A Geography 50:63-73

Wachinger G, Renn O, Begg C, Kuhlicke C (2013) The risk perception paradox implications for governance and communication of natural hazards. Risk Anal 33(6):1049-1065

White J, Fu, K-W (2012) Who do you trust? Comparing people-centered communications in disaster situations in the United States and China. Journal of Comparative Policy Analysis: Research and Practice 14(2): 126-142.

Wisner B (1993) Disaster vulnerability: scale, power, and daily life. Geojournal 30(2):127-140

Wisner B, Blaikie P, Cannon T, Davis I (2004) At risk: Natural disasters, people's vulnerability and disasters. Routledge, London

Wisner B, Kelman I, Gaillard J-C (2014) Hazard, vulnerability, capacity, risk and participation. In: López-Carresi A, Fordham M, Wisner B, Kelman I, Gaillard J-C (eds) Disaster management: International lessons in risk reduction, response and recovery. Routledge, Abingdon

Wisner B, Gaillard J-C, Kelman I (2012) Handbook of hazards and disaster risk reduction. Routledge, London

Wolf T (1878) Memoria sobre el Cotopaxi y su última erupción acaecida el 26 de junio de 1877. Imprenta, El Comercio, Guayaquil

Wynne B (1983) Redefining the issues of risk and public acceptance: the socia viability of technology. Futures 15(1):13-32

\section{Submit your manuscript to a SpringerOpen ${ }^{\circ}$ journal and benefit from:}

- Convenient online submission

- Rigorous peer review

- Immediate publication on acceptance

- Open access: articles freely available online

- High visibility within the field

- Retaining the copyright to your article

Submit your next manuscript at $\gg$ springeropen.com 